\title{
PERLINDUNGAN HUKUM TERHADAP KORBAN KEKERASAN SEKSUAL DALAM KAJIAN HUKUM ISLAM
}

\author{
Helen Intania Surayda
}

\begin{abstract}
Abstrak
Perlindungan hukum terhadap kepentingan korban kekerasan seksual baik melalui proses peradilan maupun melalui sarana kepedulian sosial, merupakan bagian kebijakan hukum. Perundang-undangan yang menjadi rujukan selama ini dalam penanganan kasus kekerasan seksual justru menjadikan perempuan sulit mengakses keadilan. Elastisitas hukum Islam sangat adaptatif dengan dinamika perubahan sosial dan kemajuan zaman. Sifat multidimensional dalam ruang lingkup hukum Islam meliputi semua aspek kehidupan manusia. Tujuan dari penetapan hukum Islam tersebut adalah mewujudkan kemaslahatan bagi umat manusia. Sebagaimana halnya pemulihan terhadap korban kekerasan seksual berhubungan dengan kemaslahatan invidividual korban

Adapun permasalahan dalam tesis ini adalah : a) bagaimana perlindungan hukum terhadap korban kekerasan seksual di tinjau dari hukum positif, b) bagaimana perlindungan hukum terhadap korban kekerasan seksual dalam konsep kajian hukum Islam ? Untuk menjawab permasalah tersebut dilakukanlah penelitian dengan metode pendekatan yuridis normatif dengan spesifikasi penelitian deskriptif analitis.Jenis data yang digunakan dalam penelitian ini adalah data sekunder.

Dari penelitian yang dilakukan diperoleh temuan perlindungan terhadap korban kekerasan seksual belum optimal difasilitasi oleh negara. Pemulihan korban kekerasan harus dimaknai secara luas, tidak saja intervensi secara medis, hukum maupun psiko-sosial, tetapi juga penciptaan situasi dimana korban kekerasan dapat kembali berdaya secara utuh, sehingga mampu mengambil keputusan-keputusan dalam hidupnya dan bisa kembali menjalankan perannya ditengah masyarakat sebagai perempuan dan warga. Hukum selalu merupakan hukum positif, dan positivisme hukum terletak pada fakta bahwa hukum itu dibuat dan dihapuskan oleh tindakan-tindakan manusia, jadi terlepas dari moralita dan sistem-sistem norma itu sendiri. Aspek maslahah mursalah jika diterapkan terhadap perlindungan hukum terhadap korban kekerasan tidak menggunakan pendekatan normatif sebagaimana yang terjadi pada umumnya akan tetapi yang digunakan adalah hak-hak korban untuk diutamakan dalam penanganannnya.
\end{abstract}

Kata kunci :Perlindungan Hukum, Korban Kekerasan, Hukum Islam 


\title{
LEGAL PROTECTION FOR THE SEXUAL VIOLENCE VICTIMS IN ISLAMIC LAW STUDY
}

\author{
Helen Intania Surayda
}

\begin{abstract}
Legal protection for the interests of sexual violence victims either through the judicial process or by means of social care, is part of the legal policy. The legislation that becomes the reference for handling the sexual violence cases makes it difficult for women to access justice. The elasticity of Islamic law is highly adaptable to the dynamics of social change and the advance of the world. Multidimensional nature within the scope of Islamic law covers all aspects of human life. The purpose of the establishment of Islamic law is to realize the benefit for mankind. Just as the recovery of sexual violence victims is related to the victim's invidual benefit.

The problems in this thesis are: a) how legal protection for sexual violence victims seen from positive law, b) how the legal protection for sexual violence victims in the concept of Islamic law study. To answer the problems, research with juridical normative approach method with specification of analytical descriptive research is conducted. The type of data used in this research is secondary data.

Based on the conducted research, it is found that protection for sexual violence victims have not been optimally facilitated by the state. The recovery of the violence victims must be broadly understood, not only in medical, legal or psycho-social interventions but also in the creation of situations in which the victims of violence can be fully empowered, so they are able to take decisions in their lives and are able to resume their roles in society as women and citizens. The law is always positive law, and the legal positivism lies on the fact that the law is created and abolished by human actions, so apart from the morality and the norm systems themselves. The aspects of maslahah mursalah if applied to the legal protection for the victims of violence do not use normative approach as the case in general but the one which is used is the rights of the victims to take precedence in its handling.
\end{abstract}

Keywords: Legal Protection, Victims of Violence, Islamic Law 


\section{PENDAHULUAN}

Kekerasan seksual menjadi
salah satu bentuk kekerasan yang
paling khas dialami oleh perempuan
karena sangat terkait dengan cara pandang mayarakat yang menempatkan perempuan sebagai obyek seksual. Berdasarkan resume data yang dilakukan oleh LRC KJHAM dari 331 kasus terhadap perempuan di Jawa Tengah sebanyak 448 perempuan menjadi korban kekerasan seksual $^{1}$. Hal ini menunjukkan segala upaya yang dilakukan untuk memperjuangkan nasib perempuan dari tindak pidana tersebut belum membawa hasil yang memuaskan bagi semua pihak. Proses penanganan kasus sejak penyidikan hingga putusan cenderung belum sepadan jika dibandingkan dengan akibat yang dialami oleh korban.

Perhatian dan perlindungan terhadap kepentingan korban kekerasan seksual baik melalui proses peradilan maupun melalui sarana kepedulian sosial tertentu

\footnotetext{
${ }^{1}$ Resume Data Penanganan Kasus LRC
} KJHAM, 2014 merupakan bagian mutlak yang perlu dipertimbangkan dalam kebijakan hukum pidana dan kebijakankebijakan sosial, baik lembaga kekuasaan negara maupun lembaga sosial yang ada. Berdasarkan tujuan dan tanggung jawab negara untuk mewujudkan pemerataan keadilan kesejahteraan umum, maka hak korban kekerasan seksual untuk dilindungi merupakan bagian integral dari hak asasi di bidang jaminan sosial.Perhatian terhadap asasi perempuan semakin meningkat membawa pengaruh dengan peningkatan perhatian terhadap masalah-masalah perempuan baik di tingkat nasional, regional maupun internasional.

Elastisitas hukum Islam sangat adaptatif dengan dinamika perubahan sosial dan kemajuan zaman. Sifat multidimensional dalam ruang lingkup hukum Islam meliputi semua aspek kehidupan manusia. Tujuan dari penetapan hukum Islam tersebut adalah mewujudkan kemaslahatan bagi umat manusia.Sebagaimana halnya pemulihan terhadap korban 
kekerasan seksual berhubungan dengan kemaslahatan invidividual korban.

\section{PEMBAHASAN}

$$
\text { Perlindungan terhadap }
$$

korban kekerasan seksual dirasakan belum optimal karena masih kurangnya pemahaman masyarakat tentang penyebab dan dampak kekerasan seksual. Hal ini ditambah dengan belum optimalnya layanan perlindungan korban yang difasilitasi oleh negara, padahal kemampuan lembaga pengada layanan berbasis masyarakat untuk memberikan layanan perlindungan korban juga terbatas. $^{2}$

Perlindungan korban dalam proses peradilan pidana tentunya tidak terlepas dari perlindungan korban menurut ketentuan hukum positif yang berlaku. Dalam hukum positif yang berlaku saat ini telah mengatur persoalan kekererasan seksual, namun semua peraturan tersebut belum sepenuhnya memahami secara komprehensif

\footnotetext{
${ }^{2}$ Booklet Komnas Perempuan, , 2013, 15 Bentuk Kekerasan Seksual Sebuah Pengenalan, Jakarta
}

persoalan yang mendalam terkait kekerasan seksual.

Terbatasnya ruang lingkup dari kekerasan seksual itu sendiri yang diatur dalam Undang-Undang Nomor 23 Tahun 2004 tentang Penghapusan Kekerasan Dalam Rumah Tangga, Undang-Undang Nomor39 Tahun 1999,Undangundang Nomor 23 Tahun 2002 sebagaimana diubah dengan UndangUndang Nomor 35 Tahun 2014 Tentang Perlindungan Anak, dan Undang-Undang Nomor 39 Tahun 1999 Tentang Hak Asasi Manusia. Terbatasnya ruang lingkup tindak pidana kekerasan seksual tersebut, membatasi persoalan-persoalan kekerasan seksual yang dialami secara nyata oleh korban.Misalnya terkait dengan pelecehan seksual, ekploitasi seksual, perkosaan, pemaksaan aborsi, perkawinan, pemaksaan pelacuran, penyiksaan seksual, dan perbudakan seksual.

$$
\text { Masih terbatasnya }
$$
pengaturan perlindungan terhadap korban dalam peraturan perundangundangan dimana korban hanya mendapat perlindungan jika menempuh proses hukum. 
Sedangkan Undang-UndangNomor 23 Tahun 2002 sebagaimana diubah dengan Undang-Undang Nomor 35 Tahun 2014 tentang Perlindungan Anak, terbatas pada perlindungan terhadap anak.

Sementara itu, ada tiga pendekatan dalam melihat apa tujuan hukum; pendekatan bahwa hukum bertujuan untuk memperoleh keadilan, menghadirkankemanfaatan, mencapai kepastian hukum, ataupun gabungan dari beberapa tujuan ini. ${ }^{3}$

Dalam perkembangan selanjutnya dirasakan ada kebutuhan bahwa hukum juga ditujukan untuk mencapai kepastian hukum. Pandangan ini dikembangkan oleh aliran Positivisme hukum, atau aliran hukum positif yang memandang perlu secara tegas ada pemisahan antara hukum dan moral; atau antara hukum yang berlaku dan hukum yang seharusnya; atau antara das sein dengan das sollen. ${ }^{4}$

Pemulihan dalam Makna Luas, dilakukan dengan lima prinsip pendekatan, yaitu:

3 Donald Albert Rumokoy dan Frans Maramis, 2014Pengantar Ilmu Hukum, Jakarta : Raja Grafindo Persada

${ }^{4}$ A. Mukhtie Fadjar, 2013Teori-teori Hukum Kontemporer, Malang : Setara Pers a. berpusat/berorientasi pada korban; Kesediaan, keterlibatan aktif dan penguatan korban merupakan inti dari proses pemulihan. Kebutuhan dan aspirasi korban adalah pertimbangan utama dari keseluruhan proses pemulihan.

b. berbasis hak; mengupayakan pemenuhan hak korban atas (1) kebenaran, (2) keadilan dan (3) pemulihan (recovery), sebagai bagian yang tak terpisahkan dari penegakan hak asasi manusia. Ketiga hak korban adalah saling terkait dan saling mempengaruhi.

c. multidimensi; untuk mencapai pemulihan yang utuh, seluruh aspek dari kehidupan korban harus memperoleh perhatian yang seimbang. Karenanya, mengupayakan aspek kesehatan fisik dan psikologis, ketahanan ekonomi dan penerimaan masyarakat adalah tak terpisahkan dari upaya 
menghadirkan rasa adil bagi korban.

d. berbasis

komunitas;

pemulihan bagi korban tidak mungkin dapat dicapai tanpa keikutsertaan aktif dari komunitasnya. Pada saat bersamaan, pemulihan bagi korban adalah bagian tak terpisahkan dari pemulihan komunitasnya.

e. berkesinambungan; proses pemenuhan hak korban atas keadilan, kebenaran dan pemulihan yang berkelanjutan. Pemulihan tidakdapat dilakukan dalam waktu yang singkat, melainkan seringkali membutuhkan waktu yang panjang.Untuk memastikan agar hak korban tidak terabaikan, proses yang panjang ini perlu terus dijaga keberlanjutannya. ${ }^{5}$

Kekerasan seksual juga menjadikan korban dan keluarganya mengalami berbagai bentuk penderitaan, karena ancaman,

${ }^{5}$ Komnas Perempuan, 2007, 13 Pertanyaan Kunci Pemulihan Dalam Makna Luas, Jakarta : Komnas Perempuan pembatasan, pengucilan/esklusi, perampasan hak serta pembedaan secara sosial, politik dan ekonomi, seperti stigma dan disalahkan oleh masyarakat dan keluarga, tidak diterima oleh keluarga, diusir dan dikucilkan olehlingkungan masyarakatnya, dikeluarkan dari sekolah atau tempat pendidikannya, dipecat dari jabatan politiknya, penghentian hubungan kerja (PHK) tanpa jaminan hak-haknya, dinikahkan secara paksa dengan pelaku, dipersulit dalam memperoleh dokumen kependudukan, tidak memperoleh berbagai jaminan sosial, tergantung secara ekonomi kepada keluarga dan orang terdekat, kehilangan hak warisnya, tidak mendapatkan layanan medis dan psikologis karena dianggap sebagai pihak yang bersalah.

Penderitaan yang berlapis dan bersifat jangka panjang yang dialami korban dan keluarganya, membutuhkan sistem penanganan, perlindungan serta pemulihan yang komprehensif, terintegrasi/terpadu, berkualitas dan berkelanjutan.

Di beberapa peraturan perundang-undangan, seperti 
Undang-Undang Nomor 11 Tahun 2012 Tentang Sistem Peradilan Pidana Anak (SPPA), ketersediaan sumber daya manusia serta infrastruktur hukum dan layanan bagi korban kekerasan seksual yang mencukupi dan berkualitas merupakan 2 (dua) elemen mendasar pra-syarat pemberlakuan undangundang. Meskipun telah disahkan pada tanggal 30 Juli tahun 2012, tetapi pemberlakuan Undang-Undang Nomor 11 Tahun 2012 baru dilakukan setelah 2 (dua) tahun terhitung sejak tanggal diundangkan.

Sistem Peradilan Pidana Terpadu Penanganan Kasus Kekerasan Terhadap Perempuan (SPPT-PKKTP) merupakan sistem terpadu yang menunjukkan proses keterkaitan antar-instansi/pihak yang berwenang menangani kasus kekerasan seksual dan akses pelayanan yang mudah dan terjangkau bagi korban dalam setiap proses peradilan kasus kekerasan seksual. SPPT-PKKTP dibangun atas dasar kebutuhan dan kepentingan korban dengan mengacu pada nilai-nilai yang adil-gender dengan mensyaratkan korban menjadi atau diletakkan pada pusat berjalannya sistem peradilan.Dalam konsep SPPT-PKKTP, korban diposisikan sebagai subjek yang berhak didengar keterangannya, mendapatkan informasi atas upayaupaya hukum yang berjalan, dipertimbangkan rasa keadilan yang ingin diperolehnya dan dipulihkan situasi dirinya atas perampasan hakhaknya dan kekerasan yang dialaminya.SPPT-PKKTP merombak kebiasaan yang umumnya menempatkan korban sebagai pelengkap (objek) yang hanya diambil keterangannya.

SPPT-PKKTP mengandung prinsip-prinsip:

a) Perlindungan dan penegakan atas hak asasi manusia dan khususnya hak asasi perempuan

b) Kesetaraan dan keadilan gender; dan

c) Non-diskriminasi.

Sebagaimana diketahui bersama bahwa tiga (3) nilai-nilai dasar yang dikemukakan oleh Gustav Radbuch dimana orientasinya adalah untuk menciptakan harmonisasi pelaksanaan hukum termasuk salah satunya adalah di Indonesia 
tentunya.Ketiga nilai dasar yang dimaksud adalah keadilan, kemanfaatan dan kepastian hukum. ${ }^{6}$

Nilai keadilan adalah bahwa perlindungan hukum korban kekerasan seksual harus mengutamakan kepentingan korban melalui cara dan situasi yang mendukung korban untuk mendapatkan haknya. Nilai kemanfaatan adalah bahwa penanganan korban kekerasan seksual harus memenuhi kebutuhan dan hak korban dan berdaya guna bagi masyarakat yang lebih luas.Nilai kepastian hukum adalah bahwa penegakan dan proses hukum pidana kekerasan seksual harus tetap dilanjutkan walaupun ada upayaupaya lain untuk menghentikan berjalan berjalannya proses hukum yang dilakukan atas nama tradisi, hukum adat, atau kondisi sosial dan politik setempat.

Undang-Undang Nomor 39

Tahun 1999 tentang Hak Asasi Manusia memang dimaksudkan sebagai peraturan perundangundangan "payung", yang hanya

${ }^{6}$ Mertokusumo, Sudikno, 2005, Mengenal Hukum: Suatu Pengantar. Yogyakarta: Liberty memuat aturan-aturan yang bersifat pokok mengenai hak asasi manusia, sedangkan pengaturan mengenai sanksi pelanggarannya dimaksudkan untuk diatur dalam peraturan perundang-undangan turunannya. Undang-Undang Nomor 23 Tahun 2004 tentang Penghapusan Kekerasan Dalam Rumah Tangga (UU PKDRT) menerjemahkan kekerasan seksual sebagai pemaksaan hubungan seksual, yang dilakukan terhadap seseorang yang posisinya sebagai pasangan suami atau istri, atau seseorang yang menetap dalam lingkup rumah tangga tersebut, atau terhadap salah seorang dalam lingkup rumah tangganya dengan orang lain untuk tujuan komersial dan/atau tujuan tertentu. Ketentuan ini pada dasarnya bisa digunakan dalam kasus perkosaan dalam perkawinan, incest (hubungan seksual dengan orang yang memiliki hubungan keturunan), ataupun pemaksaan prostitusi.Walaupun demikian, UU PKDRT menegaskan, terhadap seseorang yang posisinya sebagai pasangan suami atau istri maka 
kekerasan seksual merupakan delik aduan.

Undang-Undang Nomor 23

Tahun 2002 tentang Perlindungan Anak sebagaimana telah diubah dengan Undang-Undang Nomor 35 Tahun 2014 tentang Perubahan Atas Undang-Undang Nomor 23 Tahun 2002 tentang Perlindungan Anak (selanjutnya disebut Undang-Undang Perlindungan Anak) berlaku apabila korban adalah anak, yaitu orang yang belum mencapai usia 18 tahun. Patut diapresiasi bahwa Undang-Undang Perlindungan Anak memberikan ancaman pidana yang tinggi bagi pelaku kekerasan seksual pada anak.

Selain itu, Undang-Undang Perlindungan Anak juga menyebutkan hak atas pemulihan bagi anak yang tereksploitasi seksual, walaupun tanpa uraian lebih lanjut bagaimana hak tersebut dipastikan secara teknis dan berkesinambungan dinikmati oleh korban.Undang-Undang

Perlindungan Anak juga mengatur pemidanaan terhadap orang yang melakukan eksploitasi seksual pada anak.Mengingat ketentuan ini hanya berlaku apabila korban adalah anak, sementara tindak pidana eksploitasi seksual bisa menimpa setiap orang tak terkecuali perempuan dan anak yang berada dalam kondisi relasi kuasa yang timpang dengan pelaku.

Adapun Undang-Undang Nomor 35 Tahun 2014 tentang Perubahan Atas Undang-Undang Perlindungan Anak menyebutkan kejahatan seksual sebagai perbuatan yang dilarang dilakukan terhadap anak.Hal ini sesungguhnya merupakan kemajuan, sekaligus perlu ditingkatkan pengaturannya, mengingat kejahatan seksual juga merupakan perbuatan yang dilarang dilakukan terhadap semua orang, tak terkecuali perempuan dan anak, baik anak laki-laki maupun anak perempuan.

\section{Undang-Undang}

Perlindungan Anak tidak memidanakan 7 (tujuh) jenis kekerasan seksual lainnya dan hanya memberikan perlindungan pada anak korban perkosaan dan eksploitasi seksual. Selain itu, UU Perlindungan Anak tidak menyediakan pemidanaan dalam bentuk rehabilitasi khusus untuk mengubah perilaku dan cara pandang pelaku 
agar tidak mengulangi

perbuatannya.Bahkan, melalui

Perubahan Kedua Undang-Undang

Perlindungan Anak sebagaimana

dituangkan dalam Peraturan

Pemerintah Pengganti Undang-

Undang (Perppu)Nomor 1 Tahun

2016, justru diatur bentuk

pemidanaan kebiri kimiawi yang selain merupakan bentuk penghukuman yang kejam dan tidak manusiawi, justru membuat pelaku berupaya agar korban menghentikan perkara yang dilaporkan ke peradilan pidana. Sementara itu, apabila perkara kekerasan seksual diproses sampai adanya putusan pengadilan yang menjatuhkan pidana tambahan kebiri kimiawi, maka potensial menghamburkan belanja negara untuk tindakan yang sejauh ini tidak terbukti menjerakan pelaku.

Perlindungan hak asasi manusia dan perlindungan korban adalah ibarat dua sisi mata uang, keduanya tidak dapat dipisahkan.Penegakan hak asasi manusia dilakukan dengan melakukan perlindungan korban, demikian pula perlindungan korban diselenggarakan tanpa melanggar hak asasi manusia.

Secara umumdalam Pasal 5 Undang-Undang Perlindungan Saksi dan Korban memuat ketentuan dasar yang baik dan terperinci untuk melindungi hak-hak saksi dan koban. Undang Nomor 13 Tahun 2006 tentang Perlindungan Saksi dan Korban yang kemudian diubah menjadi Undang-Undang Nomor 31 Tahun 2014 tentang Perlindungan Saksi dan Korban mengatur norma baru yang ditambahkan pada Pasal 6. Lengkapnya berbunyi sebagai berikut:

"Korban pelanggaran hak asasi manusia yang berat, Korban tindak pidana terorisme, Korban tindak pidana perdagangan orang, Korban tindak pidana penyiksaan, Korban tindak pidana kekerasan seksual, dan korban penganiayaan berat, selain berhak sebagaimana dimaksud dalam Pasal 5, juga berhak mendapatkan:

(a) bantuan medis; dan

(b) bantuan rehabilitasi psikososial dan psikologis."

Undang-Undang Nomor 13

Tahun 2006 hanya memberikan hak 
tambahan dalam Pasal 6 tersebut bagi korban pelanggaran hak asasi manusia yang berat dan korban tindak pidana terorisme. Padahalkorban tindak pidana lainnya, tak terkecuali korban kekerasan seksual, juga memerlukan hak-hak tersebut. Dengan pengaturan baru berdasarkan UU Nomor 31 Tahun 2014 tersebut, menegaskan kewajiban Lembaga Perlindungan Saksi dan Korban (LPSK) untuk memberikan bantuan medis, rehabilitasi psikososial dan psikologis bagi korban kekerasan seksual, dimana perempuan dan anak rentan menjadi korban tindak pidana ini. $^{7}$

Mengingat kekhasan korban kekerasan seksual, perlindungan dari LPSK sangat diperlukan. Potensi viktimisasi berulang terhadap korban, keluarga korban, maupun saksi, dalam proses peradilan pidana maupun pascaputusan pengadilan diharapkan dapat dicegah dengan

7 Ema Mukarramah (editor), Menggugah Komitmen Negara Terhadap Perlindungan Perempuan Korban Kekerasan: Himpunan Naskah Usulan Terhadap Rancangan Peraturan Perundang-undangan dan Kajian Implementasi Kebijakan. Jakarta: Komnas Perempuan, 2015 adanya perlindungan tersebut. Hanya,dalam implementasinya ketentuan yang baik ini tidak otomatis berlaku bagi setiap korban kekerasan seksual, karena Penjelasan UU Nomor 35 Tahun 2014 membatasi hanya bagi anak yang menjadi korban kekerasan seksual. Rumusan yang tertuang dalam Penjelasan ini sebenarnya bertentangan dengan semangat mewujudkan jaminan konstitusional bagi warga negara, khususnya perempuan korban kekerasan seksual,atas kesamaan di hadapan hukum dan hak atas rasa aman. Seharusnya penjelasan ini diperbaiki menjadi "perempuan dan anak," agar sesuai dengan konstitusi. Perbaikan ini penting karena ada kewajiban LPSK sebagai lembaga penyelenggara Undang-Undang ini agar menjalankan tugas dan kewenangannya dengan menyandarkan pada UUD 1945. RUU Penghapusan Kekerasan Seksual membangun pembaruan atas ketentuan ini, dengan tidak lagi membedakan pemberian hak bagi korban kekerasan seksual khusus bagi perempuan atau anak saja, 
melainkan bagi setiap korban

kekerasan seksual yang pada umumnya kebanyakan adalah perempuan dan anak.

Di samping itu, dengan disebutkannya tindak pidana kekerasan seksual dalam UndangUndang Nomor 31 Tahun 2014 ini, menunjukkan bahwa RUU Penghapusan Kekerasan Seksual dibutuhkan sebagai pijakan bagi LPSK untuk memberikan perlindungan bagi korban setiap tindak pidana kekerasan seksual. Hal ini mengingat frasa "kekerasan seksual" tidak diatur oleh KUHP, sementara UU PKDRT memberikan pemaknaan sangat terbatas terhadap frasa "kekerasan seksual". Dengan menganut prinsip lex posteriori derogat legi priori (hukum yang lahir belakangan mengesampingkan hukum yang lama), maka RUU Penghapusan Kekerasan Seksual akan memberikan kepastian hukum dalam implementasi Undang-Undang Nomor 31 Tahun 2014, khususnya terkait apa saja jenis kekerasan seksual yang korbannya berhak mendapatkan perlindungan LPSK.
Pemulihan perempuan korban kekerasan harus dapat dimaknai secara luas, tidak saja intervensi yang dilakukan secara medis, hukum maupun psiko-sosial, tetapi juga penciptaan situasi dimana perempuan korban kekerasan dapat kembali berdaya secara utuh, sehingga mampu mengambil keputusan-keputusan dalam hidupnya dan bisa kembali menjalankan perannya ditengah masyarakat sebagai perempuan dan warga. Tindakan ini tidak saja menuntut keseriusan negara selaku pemikul tanggung jawab, namun juga menghendaki adanya dukungan dan keterlibatan dari masyarakat dan keluarga.

Maslahah mursalah sebagai metode hukum yang mempertimbangkan adanya kemanfaatan yang mempunyai akses secara umum dan kepentingan tidak terbatas, tidak terikat. Dengan kata lain maslahah mursalah merupakan kepentingan yang diputuskan bebas,namun tetap terikat pada konsep syari'ah yang mendasar. Karena syari'ah sendiri ditunjuk untuk memberikan kemanfaatan 
kepada masyarakat secara umum dan berfungsi untuk memberikan kemanfaatan dan mencegah kemazdaratan (kerusakan).

Hukum selalu merupakan hukum positif, dan positivisme hukum terletak pada fakta bahwa hukum itu dibuat dan dihapuskan oleh tindakan-tindakan manusia, jadi terlepas dari moralita dan sistemsistem norma itu sendiri. Norma dasar dari suatu tata hukum positif tidak lain kecuali peraturan fundamental menurut peraturan mana berbagai norma dari tata hukum positif itu harus dibuat. Norma dasar ini mengkualifikasikan suatu peristiwa tertentu sebagai peristiwa awal sebagai peristiwa awal di dalam pembentukan berbagai norma hukum. ${ }^{8}$

\section{KESIMPULAN DAN SARAN}

Perlindungan korban dalam hukum positif yang berlaku saat ini telah mengatur persoalan kekererasan seksual, namun belum sepenuhnya memahami secara

${ }^{8}$ Hans Kelsen, 1995,Teori Hukum Murni: Dasar-dasar Ilmu Hukum Normatif Sebagai IImu Hukum Empirik-Deskriptif, Rimdi Press, hlm. 115
komprehensif.SPPT-PKKTP

dibangun atas dasar kebutuhan dan kepentingan korban dengan konsep korban diposisikan sebagai subjek. Pemulihan korban kekerasan harus dapat dimaknai secara luas, tidak saja intervensi yang dilakukan secara medis, hukum maupun psiko-sosial, tetapi juga penciptaan situasi dimana korban kekerasan seksual dapat kembali berdaya secara utuh,sehingga mampu mengambil keputusan-keputusan dalam hidupnya dan bisa kembali menjalankan perannya ditengah masyarakat sebagai warga. Tindakan ini tidak saja menuntut keseriusan negara selaku pemikul tanggung jawab, namun juga menghendaki adanya dukungan dan keterlibatan dari masyarakat dan keluarga.

Dalam memberikan pelayanan kepada korban diperlukan kerjasama dalam koordinasi dan pembagian kerja yang jelas dan realistis antar lembaga, termasuk kesiapan mekanisme yang disepakati bersama dan didukung oleh kebijakan serta sumber daya yang memadai. Negara wajib melindungi warga negaranya dari rasa takut 
sebab bebas dari rasa takut adalah hak asasinya sebagai manusia.

Maslahah mursalah pada hakikatnya ada satu kesamaan yang mendasar, yaitu menetapkan hukum dalam hal-hal yang sama sekali tidak disebutkan dalam al-Qur-an maupun al-Sunnah, dengan pertimbangan untuk kemaslahatan atau kepentingan hidup manusia yang bersendikan pada asas menarik manfaat dan menghindari kerusakan. Aspek maslahah mursalah tersebut jika diterapkan terhadap perlindungan hukum terhadap korban kekerasan tidak menggunakan pendekatan normatif sebagaimana yang terjadi pada umumnya akan tetapi yang digunakan adalah hak-hak korban untuk diutamakan dalam penanganannnya.

Uraian tentang maslahat
perlindungan terhadap korban
kekerasan seksual memperhatikan 5
hal berikut:

a. Memelihara agama (hifdzu al-ddin)

b. Memelihara jiwa (hifdzul haya atau hifdzu an-Nafs)

c. Memelihara akal (hifdzul $a l-a q l)$ d. Memelihara keturunan (hifdz an-nasb)

e. Memelihara harta (hifdzu al-mal

Berdasarkan hasil penelitian dan pembahasan saran yang dapat diberikan oleh penulis adalah sebagai berikut:

1. Korban kekerasan seksual adalah subjek yang berhak didengar keterangannya, mendapatkan informasi atas upaya-upaya hukum yang berjalan, dipertimbangkan rasa keadilan yang ingin diperolehnya dan dipulihkan situasi dirinya atas perampasan hak-haknya dan kekerasan yang dialaminya. Oleh karena segala proses hukum di tujukan untuk kepentingan terbaik bagi korban.

2. Partisipasi masyarakat dperlukan dalam pengadaan, penyediaan dan pengelolaan sarana dan prasarana serta fasilitas pemulihan korban berbasis komunitas serta pemberian pertolongan darurat terhadap korban sebagi bentuk perlindungan terhadap korban proses pemulihan korban. 
3. Diperlukannya payung hukum yang mengatur secara khusus bagi korban kekerasan seksual. Kedepannya melalui payung hukum tersebut dapat memperjelas perlindungan hukum terhadap korban kekerasan seksual. Tentunya kerjasama berbagai unsur dalam masyarakat, akademisi maupun pemerintah sangat diperlukan agar tercapai implementasi yang efektif atas pemulihan korban kekerasan seksual tanpa diskriminasi.

\section{DAFTAR PUSTAKA}

Booklet Komnas Perempuan, , 2013, 15 Bentuk Kekerasan Seksual Sebuah Pengenalan, Jakarta

Donald Albert Rumokoy dan Frans Maramis, 2014, Pengantar Ilmu Hukum, Jakarta : Raja Grafindo Persada
Ema Mukarramah (editor), , 2015, Menggugah Komitmen Negara Terhadap Perlindungan Perempuan Korban Kekerasan: Himpunan Naskah Usulan Terhadap Rancangan Peraturan Perundangundangan dan Kajian Implementasi Kebijakan. Jakarta: Komnas Perempuan

Hans Kelsen, 1995,Teori Hukum Murni: Dasar-dasar Ilmu Hukum Normatif Sebagai Ilmu Hukum EmpirikDeskriptif, Rimdi Press, hlm. 115

Komnas Perempuan, 2007, 13 Pertanyaan Kunci Pemulihan Dalam Makna Luas, Jakarta : Komnas Perempuan

Mertokusumo, Sudikno, 2005, Mengenal Hukum: Suatu Pengantar. Yogyakarta : Liberty

Mukhtie Fadjar, 2013 Teori-teori Hukum Kontemporer, Malang : Setara Pers

Resume Data Penanganan Kasus LRC KJHAM, 2014 